\title{
高齢者の主観的な日常記憶の項目に関する研究
}

\author{
-2 年間の縦断的研究の結果 - \\ ○石原 治 $^{1} \cdot$ 佐々木心彩 ${ }^{2} \cdot$ 遠藤 忠 $^{2} \cdot$ 内藤佳津雄 ${ }^{2} \cdot$ 長嶋紀一 $^{2} \cdot$ 加藤伸司 $^{3}$ \\ $\left({ }^{1}\right.$ 静岡福祉大学・ ${ }^{2}$ 日本大学文理学部・ ${ }^{3}$ 認知症介護研究・研修仙台センター)
}

Key words: 日常記憶, 高齢者, 加齢

一般的に記憶や認知は加齢の影響によって低下していくと 言われている。そこで，主観的な記憶や認知に加齢がどのよ うに影響するかを明らかにするために 10 年間の縦断的な研 究を 2002 年 (平成 14 年) に開始した。

宮城県気仙沼市大島地区の 55 歳以上の島民に第 1 回目の悉 皆調査を行い, 1134 名のデータを収集した。因子分析の結果, 8 因子を抽出し，そのなかの 6 因子（「情報機器の使用」「表 情認知」「忘却」「保持」「自伝的記憶」「環境認知」「記憶補助」 「展望的記憶」）の再現性を確認した。残りの 2 因子に関して は，記憶の基本的な働きとも考えられる項目であった。1因 子は明らかに「忘却」と命名可能な因子であった。しかしな がら，もう一方の因子の項目は 3 個であり，それらは「覚え ていることが難しい」「ちょっとの間でも覚えられない」「新 しいことを覚えるのに時間がかかる」であった。前者の 2 項 目は「保持」, 後者の 1 項目は「記銘」に関すると考えられた。

記憶に関する項目に関しては，検討を重ねることが必要で あると考えた。今年一斉調査を行うが，2004 年 (平成 16 年) に2 回目の調查を行った。主観的な日常記憶に関する項目の 再検討を行った。さらにそれらの項目に対する加齢の影響を 検討することを目的として解析を行った。

\section{方 法}

対象者 宮城県気仙沼市大島地区の 55 歳以上の 1134 名が 対象者であった。第 1 回目の 75.5\%にあたる 856 名の調査協 力が得られた。その中で改訂長谷川式簡易知能評価尺度 (HDS-R）の 20 点以下の 112 名, 欠損值の多い 8 名を除き, 736 名を分析対象者とした。

質問項目 主観的な記憶に関して，「忘却」には，第 1 回 目の調查項目と同じ 2 項目 (「なにかをするはずだったのに何 であったかを忘れる」「言おうとしたことを忘れる」）および 新たに 2 項目（「覚えておかなくてはならないことを忘れる」 「覚えていたはずのことを思い出せない」）を加えた。「記銘」 には，第 1 回目と同じ 1 項目（「新しいことを覚えるのに時間 がかかる」）および新たに 1 項目（「新しいことを覚えるのは 苦手」）を加えた。

手続き 訪問調查であり，項目は「はい」「いいえ」の 2 件法であった。

\section{結 果・考 察}

(1) 調查対象者の特質 第 1 回目と第 2 回目の調査対象者 の特質を比較した (Figure 1 参照)。全般的な人数の減少傾 向がみられるのみであった。年齢構成, 性の人数の割合に違 いは見出せなかった。属性に関しても，たとえば，第 1 回目 の主観的健康感は 1.9 点，第 2 回目は 2.0 点であり，顕著な 違いは見出せなかった。

(2) 記憶の項目 主観的な記憶の 6 項目の因子分析を行った 結果, 2 因子を抽出した。それらは予め想定していた「忘却」 と「記銘」であった。加齢の影響を検討するために, 66 歳 未満（男性 88 名，女性 141 名)，67～76 歳の前期高齢者 (男 性 122 名, 女性 185 名), 77 歳以上の後期高齢者（男性 62 名, 女性 138 名)の 3 群に層別し, 標準因子得点を算出した。 因子ごとに年齢, 性を要因とする 2 要因の分散分析を行った 結果, 有意差はすべてにおいて認められなかった。これらの 結果は，加齢の影響がないことを示している。

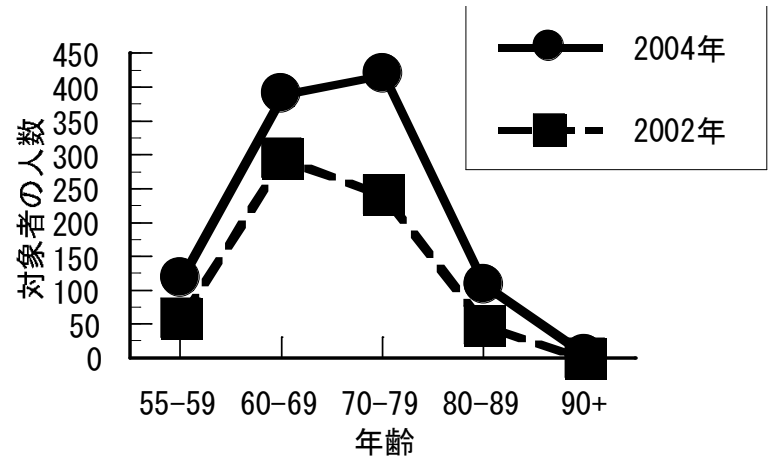

Figure 1. 対象者の推移。

(3) 記憶の項目と HDS-R との関連 HDS-R の下位尺度には 認知・記憶の実際的な測定も含まれていた。そこで, 総得点, 直後再生, 遅延再生などの得点を算出した。それらの得点と 記憶の因子得点との関連を検討するために相関係数を算出し た。その結果, すべての相関係数の值は極めて小さく, 有意 な相関係数も認められなかった。

(4) 縦断的解析 2002 年と 2004 年に共通した記憶の項目は 3 項目であった。年ごとにそれらの項目の平均得点を求め, Figure 2 に示した。「忘却」の「何かをするはずだったのに何 であったか忘れる」の項目は 2002 年が 1.23 点, 2004 年が 1.23 点であり, 得点は同じであった。しかし,「言おうとしたこと を忘れてしまう」の項目は 1.28 点, 1.16 点であり, 0.12 点悪 化していた。「記銘」の「新しいことを覚えるのに時間がかか る」は 2002 年が 1.30 点, 2004 年が 1.23 点であり, 0.07 点悪 化していた。項目ごとに繰り返しのある 1 要因の分散分析を 行った。その結果, 得点の悪化した 2 項目において有意差が 認められた。これは経年変化によって主観的な記憶が悪化し ていることを示している。しかし, 得点の変動は 1 点に満た ないことに注意を要する。加齢の影響の有無については, 本 年度の調査を加味する必要もあり, 現時点で結論を下すのは 時期尚早であると考える。

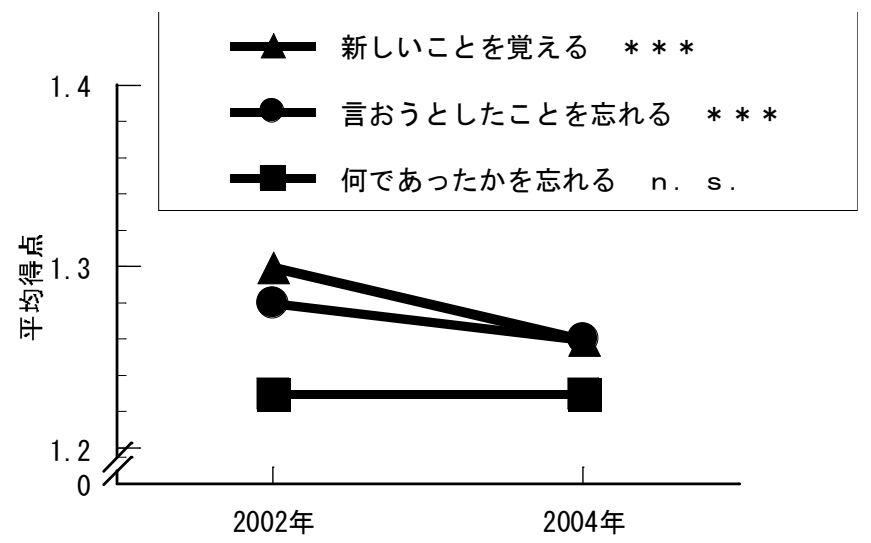

Figure 2. 記憶の項目の経年変化。

(ISHIHARA Osamu, SASAKI Shinsai, ENDO Tadashi, NAITO Katsuo, NAGASHIMA Kiichi, KATOH Shinji) 